\title{
How does service quality impact the behavioral intentions of full-service airline passengers through a hierarchical model?
}

\author{
Terrylina A. Monoarfa a and Osly Usman ${ }^{a^{*}}$
}

${ }^{a}$ Universitas Negeri Jakarta, Indonesia

\begin{tabular}{l}
\hline C H R O N I C L E \\
\hline Article history: \\
Received: May 30, 2020 \\
Received in revised format: \\
May 302020 \\
Accepted: July 6, 2020 \\
Available online: \\
July 6, 2020 \\
\hline Keywords: \\
Service quality \\
Brand experience \\
Brand credibility \\
Behavioral intention \\
\hline
\end{tabular}

A B S T R A C T

This study aims to investigate several factors that influence the behavioral intentions of full-service airlines' passengers in the air transportation industry in Indonesia. The possibility that consumers have behavioral intentions will be characterized by intention to repurchase, desire to provide recommendations to others, and have a willingness to pay a premium price. Some factors that are considered to influence behavioral intentions, both directly and indirectly, are service quality, brand credibility, and brand experience. Respondents in this study were selected based on purposive sampling with the criteria that the respondents were full-service passengers who were willing to fill out a questionnaire.

\section{Introduction}

When technology has become a daily companion in human life today, people find it easy to get information about a place in different parts of the world. This has been the main trigger why travel is the lifestyle of people today. In addition, there are many online applications that make it easy for humans to get tickets and accommodation, as well as getting other facilities while at their destination. As source shows that $90 \%$ of Gen $\mathrm{Z}$ travelers believe their international travel decisions are influenced by social media (condorferries, 2020). The current lifestyle of travel certainly provides support for airport activities that are increasingly busy in the world. People go back and forth to various countries as if each region has become borderless. Statistica.com (2019) show that in 2018, it is estimated that the number of international tourist arrivals worldwide will reach around 1.4 billion. The region with the highest annual number of visitors is Europe. However, in recent years, the Asia Pacific region has grown to become the second largest market. It is proven that Bangkok is the most desirable city as a choice of tourist destination, with 19.41 million visitors and the next is Paris with 15.45 million visitors. According to the International Airport Council (ACI), Indonesia's Soekarno-Hatta Airport in 2018 was ranked as the 18th busiest airport in the world. Where has served an average of 63 million passengers each year, both domestic and international (Yuniartha \& Winarto, 2019). The highly active air transportation industry in Indonesia is indicated by a large contribution of travel and tourism to Indonesia's GDP which increased to 62.6 billion US dollars in 2018 (knoema.com, 2018). In the air transportation industry, airlines services are generally divided into two categories, namely full-service airlines and low-cost airlines. What distinguishes the two are price, flight facilities offered, and airport categories (Refundor, 2020). In the category of full-service airlines in Indonesia there are two companies namely Garuda Indonesia and Batik Air. While low-cost airlines in Indonesia include Lion Air, AirAsia Indonesia, Citilink, Sriwijaya Air, and several others (indoindians, 2019). Garuda Indonesia (SkyTeam) as one of Indonesia's airlines serves 44 domestic destinations and 19 international destinations in 11 countries, as of June 2020 (Flightconnections, 2020). In addition, OAG as the world's leading provider of travel data and insights, has released the annual 
Punctuality League 2020 results in an industry that has Timely Performance (OTP) in the category of major airlines and airports in the world. It is seen that several Asia-Pacific airlines dominate the global ranking of 20 airlines in the world and Garuda Indonesia (GI) ranks first as the airline that has an On Time Performance (OTP) with an impressive performance of 95.01\% (Ludwell, 2020). However, based on service quality performance through consumer ratings, Skytrax determines that Garuda Indonesia is not the best airline. This is indicated by the absence of GI in the ranking list. The three best airlines in terms of service quality are occupied by Qatar Airways, Singapore Airline, and ANA Airways (worldairlineawards, 2020). Although based on the 2019 Top Brand Award it is stated that GI is in the first position as the most popular airline when compared to other airlines, with a Top Brand Index (TBI) of 40.5\% (Topbrand, 2019). Based on some of the data presented above, it is illustrated that GI actually has quite good performance. But in the midst of increasingly fierce competition in the air transportation industry in the world, it is necessary for GI to always strive to improve the quality of its services.

One factor that determines the behavioral intention towards a brand or service is the presence of good service quality (Chen, Chien Min, Hong Tau Lee, 2011; Chen, Li, \& Liu, 2018; Saha \& Theingi, 2015). If an airline provides excellent service quality to passengers, then passengers will be satisfied and have the will to be loyal to a brand (Kim \& Lee, 2011; Kos Koklic, Kukar-Kinney, \& Vegelj, 2017; Leong, Hew, Lee, \& Ooi, 2015). In fact, service quality is also indicated to have an influence on consumer considerations of brands based on their perceived experience (Moreira, Fortes, \& Santiago, 2017). Brand experience is a picture of consumers' deep responses to sensations, feelings, cognition, and behavior when using brands in the past which then influences their behavior in the future (Brakus, Schmitt, \& Zarantonello, 2009). Furthermore, brand experience will encourage the level of customer satisfaction and be a specific consideration for consumers regarding their behavioral intentions in the future (Dwivedi, Nayeem, \& Murshed, 2018; Iglesias, Markovic, \& Rialp, 2019; Iglesias, Singh, \& BatistaFoguet, 2011; Moreira et al., 2017; Prentice, Wang, \& Loureiro, 2019). In addition, service quality also has a role in influencing brand credibility and reputation (Chiu, Liu, \& Tu, 2016; Li \& Liu, 2019). Thus, with good credibility regarding airlines, it will have a positive influence on the behavioral intentions of passengers in the future (Jeng, 2016; Li \& Liu, 2019). Even, Dwivedi et al., (2018) and Erdem \& Louviere (2002) explain that brand credibility can affect airlines' willingness to pay at premium prices in the future. Conversely, when a passenger finds that the airline has not fulfilled its promise to the passenger, which makes them write comments on various media or submit their complaints to colleagues, then this will be the basis of consumer assessment of the airline's performance (Kirmani \& Rao, 2000). As in a study stated that the failure of service delivery will affect brand credibility (Bougoure, Russell-Bennett, Fazal E Hasan, \& Mortimer, 2016). Brand credibility is a fact or signal that can be captured concretely by consumers about the company's ability to fulfill its commitments to consumers, as well as testing the company's competence in the industry it does (Connelly, Certo, Ireland, \& Reutzel, 2011; Erdem \& Swait, 2004; Erdem, Swait, \& Valenzuela, 2006; Spry, Pappu, \& Cornwell, 2011). On the hands, in the air transportation industry besides service quality; brand experience and brand credibility are other important factors that consumers often consider in their behavioral intention. Some previous studies described that service quality as a factor that affects passengers' satisfaction and behavioral intentions in air transportation industry (Kim \& Lee, 2011; Kos Koklic et al., 2017; Leong et al., 2015; Martínez Caro \& Martínez García, 2007; Saha \& Theingi, 2015). Another previous study actually stated that brand experience has an influence on passengers' behavioral intention (Moreira et al., 2017; Mukerjee, 2018). Partially, another previous studies have stated that brand credibility has an influence on behavioral intention (Dwivedi et al., 2018; Jeng, 2016). While some studies explain how brand experience affects brand credibility, which indirectly encourages customers' willingness to pay premium prices (Dwivedi et al., 2018). So, the novelty of this research is to investigate how airlines are able to provide quality service performance through Hierarchical Model that is able to encourage passengers to give a positive assessment of brand experience and brand credibility. Then these factors are indicated to have an impact on the behavioral intentions of passengers from full-service airlines in the air transportation industry in Indonesia in the future. The intention of full-service airline passenger behavior is demonstrated through repurchase intentions, willingness to pay premium prices, and customer desires to recommend airlines to their social communities.

\section{Theoretical background and hypothesis development}

\subsection{Service quality}

Service quality is one of the factors that influence customer satisfaction (Leong, Hew, Lee, \& Ooi, 2015). Perceived service quality will be a measure of whether actual services perceived meet previous consumer expectations. In addition, service quality is also a factor that drives consumers to have repurchase intention in the future, as well as willingness to pay, and the desire to recommend services to others (Kim \& Lee, 2011; Ahmad et al., 2020). Measurement of service quality is formulated through five SERVQUAL dimensions (Parasuraman, V, \& Berry, 1998; Zeithaml, Berry, \& Parasuraman, 1996). The five key elements of SERVQUAL model in air transportation industry according to Nadiri, Hussain, Ekiz, \& Erdogan (2008), such as:

a. Tangibles - physical evidence embedded by objects (i.e. airline interior design, airline seat comfort, airline food quality, airline toilet cleanliness, etc.) and subjects (i.e. employee appearance, attractive uniforms, etc.).

b. Reliability - the ability of service providers to offer the accurate and trustworthy service to passengers.

c. Responsiveness - the employees' readiness to solve each passengers' needs fast and efficiently.

d. Assurance - the ability of service providers to make passengers confident, safe, and trust in service by specific service knowledge. 
e. Empathy - the willingness of employees to pay personal attention to passengers.

However, the application of the SERVQUAL model has been criticized by Cronin and Taylor (1992), that customers must provide an assessment of perceived service quality based on previous expectations at one time. This comparison between perceived service quality and customer expectations is called the SERVPERF model, which is intended to assess the quality of service performance. Furthermore, an assessment of the five dimensions of service quality in the air transportation industry is expected to focus not only on airline services, but also on airport/terminal services namely AIRQUAL model was conducted by Bari, Bavik, Ekiz, Hussain, \& Toner (2001). Other previous studies applying the AIRQUAL model were conducted by Alotaibi and John Mason (2010) and Ekiz, Hussain, \& Bavik (2015). The AIRQUAL model discusses the measurement of service quality based on dimensions:

a. Airlines tangible - the physical environment of airlines

b. Terminal tangible - the physical environment of airlines terminal or airport.

c. Personnel - the quality of airline personnel services, both at the airport terminal and during the flight.

d. Empathy - the willingness of the airlines to provide personal service for the convenience of passengers.

e. Image - the ability to present impressive images to passengers.

Whereas Brady \& Cronin (2001) described service quality in a Hierarchical Model. Where some studies have applied this service quality hierarchy model to the air transportation industry and tourism industry to assess service quality, through several dimensions (Chen, Chien Min, Hong Tau Lee, 2011; Wu \& Cheng, 2013), as follows:

a. Interaction quality - How service providers are able to provide interpersonal services to customers during service delivery. Based on many literature review, interaction quality consists of many sub-dimensions such as: attitude, behavior, and expertise, and problem solving (Martínez Caro \& Martínez García, 2007, 2008).

b. Physical environment quality - The ambience of environment which consists of sub-dimensions, such as: cleanliness, tangible, comfort, and safety and security (Park \& Almanza, 2020).

c. Outcome quality - The response shown by customers about what is obtained from the service; in other words, whether the quality of service is able to meet the needs and desires of customers. In general, the outcome quality can be categorized as: valence and punctuality (Martínez Caro \& Martínez García, 2007).

d. Access quality - Refer to the easiness to access services. Access quality is based on two specific sub-dimensions: information and convenience (Brady \& Cronin, 2001; Chen, Chien Min, Hong Tau Lee, 2011; Wu \& Cheng, 2013).

Based on previous research, this study will apply service quality measurements based on a hierarchical model. This is performed with the consideration that the hierarchical model will be able to dig deeper into the customer's response to the service provided by the airline company. This includes the quality of interpersonal services (interaction quality), the quality of services in terms of the physical environment (physical environment quality), as well as the quality of the service after the service is delivered to the customer (outcome quality), such as how to provide services when passengers wait at the airport arrival terminal, and quality of access that illustrates how the airline has the feasibility to convey information aimed at saving customer resources.

\subsection{Behavioral Intention}

Behavioral intention can be defined as the possibility of subjective confirmation of the customer to the performance that drives certain behavioral acts (Lai \& Chen, 2011). Service quality is one of many factors which drive customers' behavioral intention (Rajaguru, 2016). In general, behavioral intentions play a role in driving profitability and market share of the company, as indicated by the following customer behaviors:

a. Word of mouth (WOM) communication - Customer volunteerism to communicate the information of their excitement about product or service with other customers.

b. Repurchase intention - Customer desire to make repeat purchases and increase their future purchases.

c. Willingness to pay - Customer willingness to pay at any price determined by the company to buy a product or service.

When customers feel a deep impression of a product or service, often customers are joyfully to share that information to other customers. It even allows customers to indirectly show persuasive attitudes to others and recommend brands. As in a study mentioned that excellent service quality encourages customer intentions to do WOM (Chiu et al., 2016; Mukerjee, 2018; Ngo, Northey, Duffy, Thao, \& Tam, 2016). Likewise, when customers find impressive services, customers will tend to assess and evaluate the performance of a brand, which will encourage customers' intention to repurchase the same brand in the future, or even increase their amount of purchases (Chen et al., 2018; Kos Koklic et al., 2017; Saha \& Theingi, 2015). Other research states that excellent service quality encourage customers' willingness to pay. Even when a brand is embedded in their minds, customers tend to be willing to pay even at premium prices (Dwivedi et al., 2018; Nikhashemi, Jebarajakirthy, \& Nusair, 2019). 
Hypothesis 1. Service Quality has a positive directly effect on behavioral intention.

\subsection{The mediating role of Brand Experience and Brand Credibility in affecting Behavioral Intention}

\section{a. Brand Experience}

There are many constructs and measurements that have been developed previously in the branding literature, including brand personality and brand attachment (Aaker, 1996). However, brand experience has a different meaning from brand personality or brand attachment. Brand personality and brand attachment are generally built by evaluative, affective, and associative dimensions (Brakus et al., 2009). Whereas brand experience can be defined as subjective and internal customer responses, where experience is felt deeply by customers, not only is overall 'likes' expressed enough through "I like this brand", but can be more emotional, such "I am impressed with this brand". Dolbec and Chebat (2013) explain that a positive experience can stimulate the sensory and make customers bound to a brand through emotions, cognition, and body experience. As it develops, brand experience can influence customer evaluations and general attitudes, especially experience evaluations. In addition, brand experience may also result an emotional bond to a brand. Zarantonello and Schmitt (2013) and Sahin, Kitapçi, Altindag, \& Gök (2017) explained that brand experience consists of four dimensions, such as:
a. Sensory - the visual, auditory, tactile, gustatory and olfactory stimulations provided by brands.
b. Affective - moods and emotions.
c. Intellectual - convergent/analytical thinking and divergent/imaginative thinking.
d. Behavioral - actions, bodily, and interactive experiences.

Nysveen, Pedersen, \& Skard (2013) concluded that the dimension of brand experience is particularly useful for service industry or service brands. It related to other research as explained by Khan \& Rahman (2015) that in retail industry, retailers should provide well-managed brand experience to enhance customers' satisfaction and loyalty thereby improving profitability of retailers. Whereas in retail banking industry, other study concluded that brand experience of retail bank customers have an impact on Word-of-Mouth (WOM), even more the sensory experience can enhance brand trust and loyalty (Mukerjee, 2018). In the air transportation industry, a research finding concludes that brand experience can be stimulated by providing the best quality service, such as how flight attendants provide excellent service while on a flight. Indirectly it will encourage brand love and have a sustainable effect on increasing customer engagement (Prentice et al., 2019). Most of studies stated that service quality and brand experience partially has an important role regarding to enhance customer satisfaction and behavioral intention (Kim \& Lee, 2011; Leong et al., 2015; Mukerjee, 2018; Saha \& Theingi, 2015). However, Prentice et al. (2019) argued the quality of flight services assessed by passengers has a moderate role for brand experience, brand love, and brand engagement in the chain of relationships. Quality of service reflects the cognitive assessment of the service provided by the brand. In customer perception, each brand must provide excellent service as proof of its competitiveness in the industry. For example, in the air transportation industry, there are many airlines on the same route that offer services to deliver passengers to their destinations. The choice and decision depend on the customer's personal judgment and experience or from others. Accordingly, the hypotheses are stated as follows:

Hypothesis 2. Service quality has a positive effect on brand experience.

Hypothesis 3. Brand Experience has a positive effect on behavioral Intention.

\section{b. Brand Credibility}

Brand is the most important thing to identify products or services by a name, symbol, tagline, design, logo, or combination of them to differentiate with competitors (Aaker, 1996). According to Bong na, Marshall, \& Keller (1999) and Keller (2005) brand credibility is a key element in the customer-based brand equity pyramid. Which explains that brand credibility is the basis for consideration of customers responding to a brand from time to time. Brand credibility is an extension of the brand signaling theory, which explains that brand credibility depends on asymmetric information captured by customers (Connelly et al., 2011; Erdem et al., 2006; Kirmani \& Rao, 2000), whether the information is sent directly by the company or the information has become a public customer conversation which then influences other customers' decisions when choosing a brand (Connelly et al., 2011). When a brand provides information to the market, related to prices, promotions, characteristics of goods and services, or how a brand responds to consumer complaints, it is captured by the market as asymmetric information that drives consumers' assessment of brand credibility (Spry et al., 2011). Based on brand credibility, it will affect how customers make decisions about various brand choices in the future (Erdem \& Swait, 2004). Signaling theory postulates that a brand is considered credible by customers when they receive signals based on all information that the brand believable and trustworthy (Shafranskaya \& Potapov, 2014; Sweeney \& Swait, 2008). This is related to how a brand has the ability to realize a product or service in accordance with their commitments and fulfil what is promised. In addition, the credibility of a brand can also be measured when the brand has the competence and expertise in accordance with its industrial field. Credible brands will tend to be truthful with their products and services. Besides, the brand must know how to find the right way to communicate it and try to make customers receive a positive signal in order to minimize the amount of complaints from customers. This implies that a brand can be called capable of providing a credible signal when the brand embodies all the 
cumulative efforts of marketing communication strategies (Baek, Kim, \& Yu, 2010). So, it can be concluded that the essence of brand signaling is brand credibility. The concept of credibility has two main dimensions (Jeng, 2016; Sweeney \& Swait, 2008):

a. Trustworthiness - Brand's willingness to give as promised

b. Expertise - The ability to deliver and realize

In the study explained that service quality affects purchase intentions because of the moderating influence of the company's reputation (Chiu et al., 2016). The reputation of the company or brand is a marketing signal that is able to predict future market behavior. This is relevant to Connelly et al. (2011) that information received by customers will be considered by customers to reuse the same brand in the future. As stated that in the service industry, service quality is a major contributor to create marketing signal which affecting credibility (Greenwood et al., 2017; Muslim et al., 2020). There is a congruence between the service that the customer expects compared to the perceived service that will form a marketing signal, which will be a benchmark for the customer in evaluating the performance of the brand or company (Kirmani \& Rao, 2000). Whereas different research states that the high number of customer complaints is a signal of failure of a brand or company in providing excellent service quality, so that customers experience dissatisfaction with the brand or company (Bougoure et al., 2016; Li \& Liu, 2019). In another study it was stated that when a brand gives signals or asymmetric information to the market that there are conditions of uncertainty, this will encourage customers to assess the credibility of a brand, which impacts the level of customer sensitivity to prices (Erdem \& Louviere, 2002). Vice versa, when a brand provides excellent service quality, then it will encourage customers to tend to give a positive assessment of brand credibility. This is illustrated through the willingness of customers to pay even at premium prices (Dwivedi et al., 2018). Accordingly, the hypothesis are stated as follows:

Hypothesis 4. Service quality has a positive effect on brand credibility.

Hypothesis 5. Brand credibility has a positive effect on behavioral intention.

\subsection{Brand Experience and Brand Credibility}

When a brand provides quality service, it will form a memorable experience for customers about how they feel when using a brand at the time. Positive brand experience is a marketing signal or asymmetric information that will influence customers when considering their decision to make brand choices. So it can be concluded that brand experience influences the formation of brand credibility that impacts long-term customer behavioral intentions (Dwivedi et al., 2018; Nusairat et al., 2020). Accordingly, the hypothesis is stated as follows:

Hypothesis 6. Brand experience has a positive effect on brand credibility.

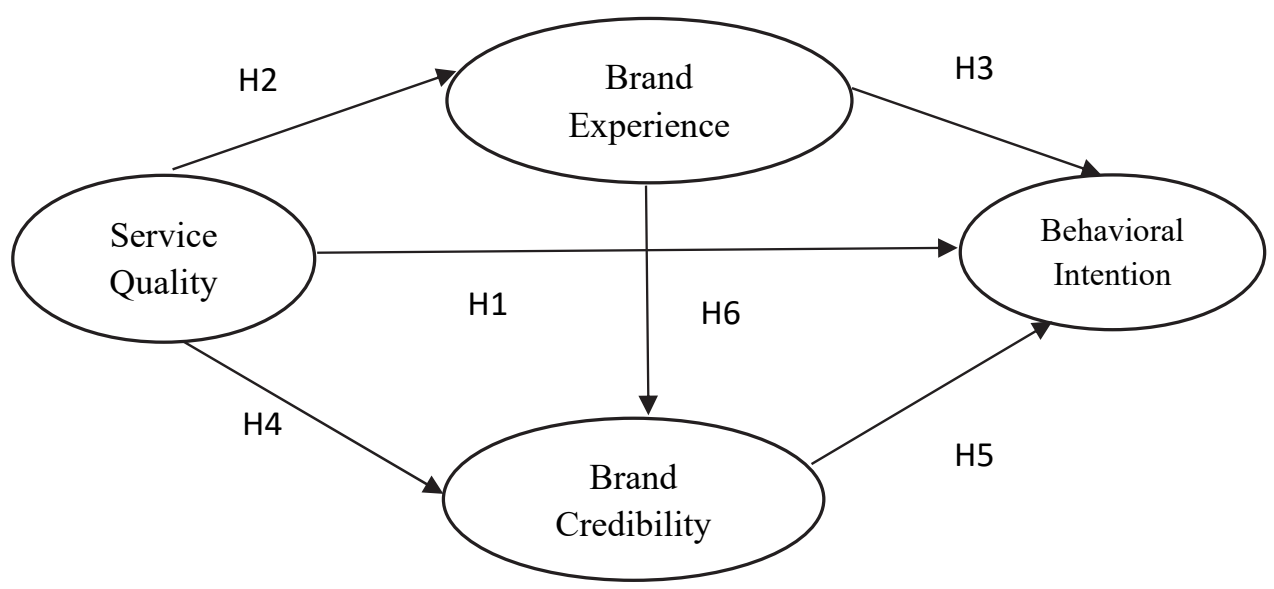

Fig. 1. The proposed method

\section{Methodology}

\subsection{Sample and procedures}

This study proposes non-probability sampling where each one has different opportunity to be selected as a respondent. Samples in this research were selected by purposive technique sampling which proposed specific criteria for selecting respondent through screening question. Respondents in this study were full-service airline passengers, who had used services through Jakarta's Soekarno-Hatta airport, which at least had used the service once a year. 
This questionnaire will arrange by several part. The first is respondent profile which consist of many questions about gender, age, occupation, average income, how often use the brand of airline, and what the purpose of having flight with this brand of airline. Then, second part is there are many statements to measure the variables which respondent must fill with the degree of agreement by Likert scale five point, where 1 represents strongly disagree and 5 point means strongly agree. The operasinalization of variables penjelasan pengukuran variabel will explain the ability of dimensions and indicator to illustrate how affectively the independent variable affected the dependent variable. Accordingly, the operasionalization of variables are stated as follow:

\subsection{Variables and measurements}

Description of the variables and measurements

\begin{tabular}{|c|c|c|c|c|}
\hline Variable & Dimension & Sub-dimension & Items & Reference \\
\hline \multirow{12}{*}{$\begin{array}{l}\text { Service } \\
\text { Quality }\end{array}$} & \multirow{4}{*}{$\begin{array}{l}\text { SQ1. Interaction Qual- } \\
\text { ity }\end{array}$} & SQ1a. Attitude & I can count on the personnel being friendly & \multirow{4}{*}{$\begin{array}{l}\text { (Martínez Caro \& } \\
\text { Martínez García, } \\
\text { 2007) }\end{array}$} \\
\hline & & SQ1b. Behavior & I can count on personnel taking actions to address my need & \\
\hline & & SQ1c. Expertise & Personnel are able to answer my questions quickly & \\
\hline & & $\begin{array}{l}\text { SQ1d. Problem } \\
\text { Solving }\end{array}$ & $\begin{array}{l}\text { When a customer has a problem, airline company shows a sin- } \\
\text { cere interest in solving it }\end{array}$ & \\
\hline & \multirow{4}{*}{$\begin{array}{l}\text { SQ2. Physical Envi- } \\
\text { ronment Quality }\end{array}$} & SQ2a. Cleanliness & The toilet in the cabin is clean. & \multirow{4}{*}{$\begin{array}{l}\text { (Wu \& Cheng, } \\
\text { 2013) }\end{array}$} \\
\hline & & SQ2b. Comfort & Flying an airplane is comfortable. & \\
\hline & & SQ2c. Tangible & The on-site queuing at the airport is appropriate. & \\
\hline & & $\begin{array}{l}\text { SQ2d. Safety and } \\
\text { Security }\end{array}$ & There are accessible fire exits in the cabin. & \\
\hline & \multirow[t]{2}{*}{ SQ3. Outcome Quality } & SQ3a. Valence & $\begin{array}{l}\text { When the flight service is complete, I usually feel that I have a } \\
\text { wonderful flight with this airline. }\end{array}$ & \multirow{2}{*}{$\begin{array}{l}\text { (Martínez Caro \& } \\
\text { Martínez García, } \\
\text { 2007) }\end{array}$} \\
\hline & & SQ3b. Punctuality & The airline company is trying to keep flights on schedule & \\
\hline & \multirow{2}{*}{ SQ4. Access Quality } & $\begin{array}{l}\text { SQ4a. Conven- } \\
\text { ience }\end{array}$ & Easy ticket booking system. & \multirow{2}{*}{$\begin{array}{l}\text { (Wu \& Cheng, } \\
\text { 2013) }\end{array}$} \\
\hline & & $\begin{array}{l}\text { SQ4b. Infor- } \\
\text { mation }\end{array}$ & Information provided by the official airline website is reliable. & \\
\hline \multirow[t]{4}{*}{$\begin{array}{l}\text { Brand Ex- } \\
\text { perience }\end{array}$} & BE1. Sensory & & The airline gives a strong impression on my visual senses & \multirow{4}{*}{$\begin{array}{l}\text { (Dwivedi et al., } \\
\text { 2018; Sahin et al., } \\
\text { 2017) }\end{array}$} \\
\hline & BE2. Emotional & & I have strong bond for this airline. & \\
\hline & BE3. Behavioral & & The airlines provide comfort when sitting along in flight. & \\
\hline & BE4. Intellectual & & $\begin{array}{l}\text { This airline stimulates my curiosity about how this airline will be } \\
\text { in the future. }\end{array}$ & \\
\hline \multirow{2}{*}{$\begin{array}{l}\text { Brand } \\
\text { Credibility }\end{array}$} & BC1. Trustworthiness & & Airline has a brand you can trust. & \multirow{2}{*}{$\begin{array}{l}\text { (Dwivedi et al., } \\
\text { 2018) }\end{array}$} \\
\hline & BC2. Expertise & & Brand of airline has the ability to deliver what it promises. & \\
\hline \multirow{3}{*}{$\begin{array}{l}\text { Behavioral } \\
\text { Intention }\end{array}$} & $\begin{array}{l}\text { BI1. WOM Communi- } \\
\text { cation }\end{array}$ & & I say positive things about this brand to other people & (Sahin et al., 2017) \\
\hline & $\begin{array}{l}\text { BI2. Repurchase In- } \\
\text { tention }\end{array}$ & & I consider this brand as my first choice in airline industry. & \multirow{2}{*}{$\begin{array}{l}\text { (Sahin et al., 2017) } \\
\text { (Dwivedi et al., } \\
\text { 2018; Sahin et al., } \\
\text { 2017) }\end{array}$} \\
\hline & $\begin{array}{l}\text { BI3. Willingness to } \\
\text { Pay Premium Price }\end{array}$ & & $\begin{array}{l}\text { I am willing to pay a higher price to get exclusive facility from } \\
\text { this airline. }\end{array}$ & \\
\hline
\end{tabular}

\section{Result and Discussion}

Fig. 2 shows the proposed study of this paper.

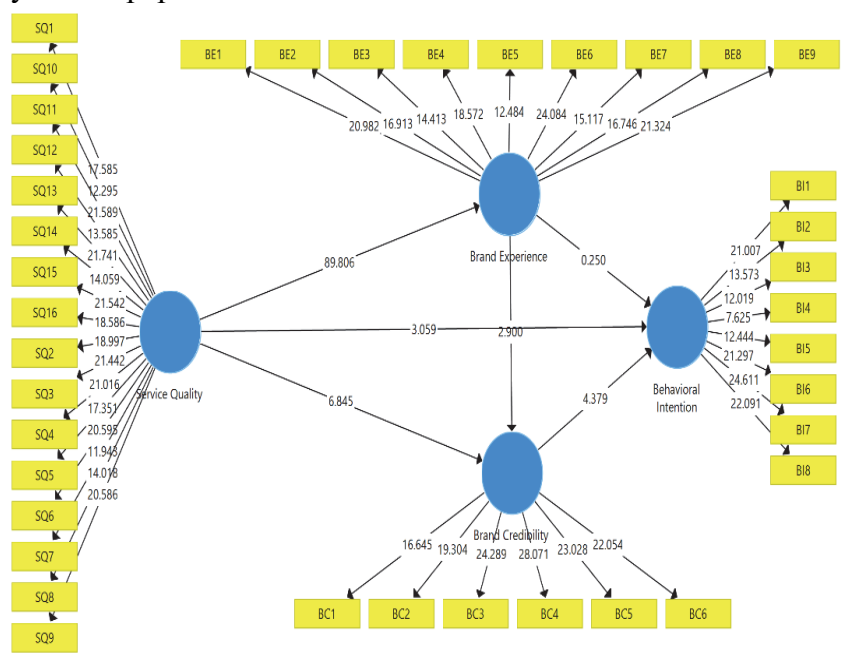

Fig. 2. Outer Model

Source: data processed by researchers (2020) 
Analysis of the model outer aims to determine how the relationship between the latent variables with each indicator. Cronbach's alpha value is used to determine the level indicator of each construct validity. If the Cronbach alpha value is more than 0.6 , then the construction is declared valid, and vice versa. The results of the alpha Cronbach calculation are shown in the following table.

\section{Table 1}

Cronbach's Alpha

\begin{tabular}{lc}
\hline Cronbach's Alpha & 0.896 \\
\hline Behavioral Intention & 0.895 \\
Brand Credibility & 0.915 \\
Brand Experience & 0.953 \\
Service Quality & \\
\hline
\end{tabular}

Source: data processed by researchers (2020)

According to Table 1, Cronbach's alpha value for Behavioral Intention, Brand Credibility, Brand Experience and Service Quality were $0.896,0.895,0.915$, and 0.953 , respectively. The results show that the value of all Cronbach's alpha variables is more than 0.6 . It can be concluded that all constructs on the variables used in this study are valid. Furthermore, to determine the value of the reliability indicator can be measured using the value of Average Variance Extracted (AVE) and Composite Reliability (CR). The AVE value obtained shows the variance of each variable. Testing criteria for AVE is above 0.5 . That is, the higher the AVE, the better, and shows a growing diversity of indicators. Meanwhile, the criteria for testing the value of composite reliability are above 0.7 . The higher the $\mathrm{CR}$, the higher the variable reliability value.

Table 2

Average Variance Extracted (AVE) and Composite Reliability (CR)

\begin{tabular}{ccc}
\hline & Composite Reliability (CR) & Average Variance Extracted (AVE) \\
\hline Behavioral Intention & 0.917 & 0.580 \\
Brand Credibility & 0.919 & 0.655 \\
Brand Experience & 0.930 & 0.596 \\
Service Quality & 0.958 & 0.587 \\
\hline Source: & &
\end{tabular}

Source: data processed by researchers (2020)

Table 2 shows that the value of Composite Reliability in Behavior Intentions is 0.917, Brand Credibility 0.919, Brand Experience 0.930, and Service Quality 0.958. Then, the value of Average Variance Extracted (AVE) in Behavioral Intention is 0.580, Brand Credibility 0.655, Brand Experience 0.596, and Service Quality 0.587. All value of Average Variance Extracted (AVE) are above 0.5 and Composite Reliability values are above 0.7 . It can be concluded that all variables in this study revealed reliable.

Analysis Inner Model

Table 3

R-Square $\left(\mathrm{R}^{2}\right)$

\begin{tabular}{cc}
\hline & R Square \\
\hline Brand Experience & 0.898 \\
\hline Brand Credibility & 0.915 \\
\hline Behavioral Intention & 0.924 \\
\hline & Source: data processed by researchers (2020)
\end{tabular}

Based on Table 3, it can be concluded that:

1. R-squared Model I is 0.898 , it can define the ability construct of Service Quality in explaining the construct Brand Experience by 89,8 percent (high).

2. R-Square Model II is 0.915 , it can define the ability construct of Service Quality and Brand Experience in explaining the constructs Brand Credibility by 91,5 percent (high).

3. R-Square Model III is 0.924, it can define the ability construct of Service Quality, Brand Experience and Brand Credibility in explaining the construct Behavioral Intention by 92,4 percent (high).

Table 4

f-Square $\left(f^{2}\right)$

\begin{tabular}{cccc}
\hline & Behavioral Intention & Brand Credibility & Brand Experience \\
\hline Behavioral Intention & & & \\
\hline Brand Credibility & 0.375 & & \\
\hline Brand Experience & 0.001 & 0.102 & \\
\hline Service Quality & 0.119 & 8.759 & \\
\hline
\end{tabular}


According to Table 3, the relationship between construct Service Quality and Behavioral Intention is 0.119. It can interpret that there is a strong relationship between those variables. The relationship between construct Brand Experience and Behavioral Intention is 0.001 . It can interpret that the relationship of variables is quietly strong. The relationship between construct Brand Credibility and Behavioral Intention is 0.375 . It can interpret that the relationship of variables is quietly strong. The relationship between construct Service Quality and Brand Credibility is 0.547 . It can be interpreted that there is strong relationship between them. The relationship between construct Brand Experience and Brand Credibility is 0.102 and it can interpret that there is strong relationship. Then, the relationship between construct Service Quality and Brand Experience is 8.759 which can interpret that there is very strong relationship.

\section{Hypothesis Test}

After testing the analysis of internal and external models, the next step is to analyze the measurement of the relationship or the relationship between structural constructions (hypothesis testing). According to Ghazali and Latan (2015) in hypothesis testing can be described by t-statistic value and probability value. Testing the hypothesis using a statistical value for alpha $5 \%$ of the t-statistics used was 1.96. The criterion for acceptance or rejection of the hypothesis is $\mathrm{Ha}$ is accepted and $\mathrm{H}_{0}$ is rejected, when the t- statistic is more than 1.96 and the probability value is less than 0.05 .

\section{Table 5}

Path Coefficient

\begin{tabular}{|c|c|c|c|c|c|}
\hline & Original Sample (O) & $\begin{array}{l}\text { Sample Mean } \\
\text { (M) }\end{array}$ & $\begin{array}{c}\text { Standard Deviation } \\
\text { (STDEV) }\end{array}$ & $\begin{array}{l}\text { T Statistics } \\
(|\mathrm{O} / \mathrm{STDEV}|)\end{array}$ & P Values \\
\hline Brand Credibility $\rightarrow$ Behavioral Intention & 0.576 & 0.576 & 0.132 & 4.379 & 0.000 \\
\hline Brand Experience $\rightarrow$ Behavioral Intention & 0.328 & 0.324 & 0.114 & 3.250 & 0.003 \\
\hline Brand Experience $\rightarrow$ Brand Credibility & 0.292 & 0.293 & 0.101 & 2.900 & 0.004 \\
\hline Service Quality $\rightarrow$ Behavioral Intention & 0.369 & 0.375 & 0.121 & 3.059 & 0.002 \\
\hline Service Quality $\rightarrow$ Brand Credibility & 0.676 & 0.675 & 0.099 & 6.845 & 0.000 \\
\hline Service Quality $\rightarrow$ Brand Experience & 0.947 & 0.948 & 0.011 & 89.806 & 0.000 \\
\hline
\end{tabular}

Source: data processed by researchers (2020)

H1: Service Quality has a positive effect on Behavioral Intention.

Based on the calculation of coefficient path, it describes that value of Original Sample 0.369, T-Statistics 3.059 is more than 1.96 and $\mathrm{P}$ value is 0.002 that less than 0.05. It may conclude that Service Quality has a positive effect on Behavioral Intention significantly.

$\mathbf{H}_{2}$ : Service Quality has a positive effect on Brand Experience.

Based on the calculation of coefficient path, it describes that value of Original Sample 0.947, T-Statistics 89.806 is more than 1.96 and $\mathrm{P}$ value is 0.000 that less than 0.05. It may conclude that Service Quality has a positive effect on Brand Experience significantly.

$\mathbf{H}_{3}$ : Brand Experience has a positive effect on Behavioral Intention.

Based on the calculation of coefficient path, it describes that value of Original Sample 0.328, T-Statistics 3.250is more than 1.96 and $\mathrm{P}$ value is 0.003 that less than 0.05. It may conclude that Brand Experience has a positive effect on Behavioral Intention significantly.

\section{$\mathrm{H}_{4}$ : Service Quality has a positive effect on Brand Credibility}

Based on the calculation of coefficient path, it describes that value of Original Sample 0.676, T-Statistics 6.845 is more than 1.96 and $\mathrm{P}$ value is 0.000 that less than 0.05 . It may conclude that Service Quality has a positive effect on Brand Credibility significantly.

\section{Hs: Brand Credibility has a positive effect on Behavioral Intention}

Based on the calculation of coefficient path, it describes that the value of Original Sample 0.576, T-Statistics 4.379 is more than 1.96 and $\mathrm{P}$ value is 0.000 that less than 0.05. It may conclude that Brand Credibility has a positive effect on Behavioral Intention significantly.

\section{H6: Brand Experience has a positive effect on Brand Credibility}

Based on the calculation of coefficient path, it describes that value of Original Sample 0.292, T-Statistics 2.900 is more than 1.96 and $\mathrm{P}$ value is 0.004 that less than 0.05. It may conclude that Brand Experience has a positive effect on Brand Credibility 
significantly. According to Table 6, assessing the effect of variables Brand Experience on Behavior Intention with Brand Credibility as a mediating variable is to consider to the Original Sample value of 0.168 , T-Statistics of 2.196 which is more than 1.96, and $\mathrm{P}$ values of 0.002 which is less than 0.05 . Thus, it can be concluded that Brand Experience has a positive effect on Behavioral Intention significantly, with Brand Credibility as a mediating variable.

To determine the effect of Service Quality on Brand Credibility with Brand Experience as a mediating variable we need to consider the Original Sample value of 0.276, T-Statistics of 2.887 which is more than 1.96 and $\mathrm{P}$ value of 0.004 and is less than 0.05 Thus, it can be concluded that Service Quality has a positive effect on Brand Credibility significantly, with Brand Experience as a mediating variable. The effect of Service Quality on Behavioral Intention with Brand Credibility as a mediating variable is to consider to the Original Sample value of 0.389, T-Statistics of 4.100 which is more than 1.96 and $\mathrm{P}$ of 0.000 which less than 0.05. Thus, it can be concluded that the Quality Service has a positive effect on Behavioral Intention significantly, with Brand Credibility as a mediating variable. Furthermore, to determine the effect of Service Quality on Behavioral Intention with Brand Experience as a mediating variable is to consider to the Original Sample values of 0.027, TStatistics of 3.249 which is more than 1.96 and $\mathrm{P}$ of 0.003 which is less than 0.05 . Thus, it can be concluded that Quality Service has a positive effect on Behavioral Intention with Brand Experience as a mediating variable.

Table 6

Indirect Effect

\begin{tabular}{|c|c|c|c|c|c|}
\hline & $\begin{array}{c}\text { Original } \\
\text { Sample }(\mathrm{O})\end{array}$ & $\begin{array}{c}\text { Sample } \\
\text { Mean (M) }\end{array}$ & $\begin{array}{l}\text { Standard Deviation } \\
\text { (STDEV) }\end{array}$ & $\begin{array}{l}\text { T Statistics } \\
(|\mathrm{O} / \mathrm{STDEV}|)\end{array}$ & P Values \\
\hline Brand Experience $\rightarrow$ Brand Credibility $\rightarrow$ Behavioral Intention & 0.168 & 0.171 & 0.077 & 2.196 & 0.002 \\
\hline Service Quality $\rightarrow$ Brand Experience $\rightarrow$ Brand Credibility & 0.276 & 0.277 & 0.096 & 2.887 & 0.004 \\
\hline Service Quality $\rightarrow$ Brand Credibility $\rightarrow$ Behavioral Intention & 0.389 & 0.386 & 0.095 & 4.100 & 0.000 \\
\hline Service Quality $\rightarrow$ Brand Experience $\rightarrow$ Behavioral Intention & 0.027 & 0.322 & 0.088 & 3.249 & 0.003 \\
\hline $\begin{array}{c}\text { Service Quality } \rightarrow \text { Brand Experience } \rightarrow \text { Brand Credibility } \rightarrow \\
\text { Behavioral Intention }\end{array}$ & 0.159 & 0.163 & 0.073 & 2.185 & 0.002 \\
\hline
\end{tabular}

Source: data processed by researchers (2020)

\section{Conclusion}

1. The result of the first hypothesis indicates Service Quality has a positive effect on Behavioral Intention. Based on the calculation of coefficient path, it describes the value of Original Sample 0.369, T-Statistics 3.059 is more than 1.96 and $\mathrm{P}$ value is 0.002 that less than 0.05. It may conclude that Service Quality has a positive effect on Behavioral Intention significantly.

2. The result of the second hypothesis indicates Service Quality has a positive effect on Brand Experience. Based on the calculation of coefficient path, it describes that value of Original Sample 0.947, T-Statistics 89.806 is more than 1.96 and $\mathrm{P}$ value is 0.000 that less than 0.05 . It may conclude that Service Quality has a positive effect on Brand Experience significantly.

3. The result of the third hypothesis Brand Experience has a positive effect on Behavioral Intention. Based on the calculation of coefficient path, it describes that value of Original Sample 0.328, T-Statistics 3.250is more than 1.96 and $\mathrm{P}$ value is 0.003 that less than 0.05. It may conclude that Brand Experience has a positive effect on Behavioral Intention significantly.

4. The result of the four hypothesis Service Quality has a positive effect on Brand Credibility. Based on the calculation of coefficient path, it describes that value of Original Sample 0.676, T-Statistics 6.845 is more than 1.96 and $\mathrm{P}$ value is 0.000 that less than 0.05. It may conclude that Service Quality has a positive effect on Brand Credibility significantly.

5. The result of the five hypothesis Brand Credibility has a positive effect on Behavioral Intention. Based on the calculation of coefficient path, it describes that the value of Original Sample 0.576, T-Statistics 4.379 is more than 1.96 and P value is 0.000 that less than 0.05. It may conclude that Brand Credibility has a positive effect on Behavioral Intention significantly.

6. The result of the s hypothesis Brand Experience has a positive effect on Brand Credibility. Based on the calculation of coefficient path, it describes that value of Original Sample 0.292, T-Statistics 2.900 is more than 1.96 and P value is 0.004 that less than 0.05. It may conclude that Brand Experience has a positive effect on Brand Credibility significantly.

\section{Acknowledgement}

The authors would like to thank the anonymous referees for constructive comments on earlier version of this paper 


\section{References}

Aaker, D. A. (1996). Measuring brand equity across products and markets. California Management Review, 38(3), $102-120$.

Ahmad, A., Abuhashesh, M., Obeidat, Z., \& AlKhatib, M. (2020). E-WOM and airline e-ticket purchasing intention: Mediating effect of online passenger trust. Management Science Letters, 10(12), 2729-2740.

Alotaibi, M. M., \& John Mason, K. (2010). Evaluation of "AIRQUAL" Scale for Measuring Airline Service Quality and Its Effect on Customer Satisfaction and Loyalty. Cranfield University.

Baek, T. H., Kim, J., \& Yu, J. H. (2010). The differential roles of brand credibility and brand prestige in consumer brand choice. Psychology \& Marketing, 27(7), 662-678.

Bari, Bavik, A., Ekiz, E. H., Hussain, K., \& Toner, S. (2001). AIRQUAL: A Multiple-Item Scale for Measuring Service Quality, Customer Satisfaction, and Repurchase Intention. Eastern Mediterranean University.

Bong na, W., Marshall, R., \& Keller, K. L. (1999). Measuring Brand Power: Validating A Model for Optimizing Brand Equity. Journal of Product \& Brand Management, 8(3), 170-184.

Bougoure, U., Russell-Bennett, R., Fazal E Hasan, S., \& Mortimer, G. (2016). The impact of service failure on brand credibility. Journal of Retailing and Consumer Services, 31, 66-71.

Brady, M. K., \& Cronin, J. J. (2001). Some new thoughts on conceptualizing perceived service quality: A hierarchical approach. Journal of Marketing, 65(3), 34-49.

Brakus, J. J., Schmitt, B. H., \& Zarantonello, L. (2009). Brand experience: What is it? How is it measured? Does it affect loyalty? Journal of Marketing, 73(3), 52-68.

Chen, C. M., Lee, H. T., Chen, S. H., \& Huang, T. H. (2011). Tourist behavioural intentions in relation to service quality and customer satisfaction in Kinmen National Park, Taiwan. International Journal of Tourism Research, 13(5), 416-432..

Chen, L., Li, Y., \& Liu, C. (2018). How airline service quality determines the quantity of repurchase intention - Mediate and moderate e ff ects of brand quality and perceived value. Journal of Air Transport Management, (July), 0-1.

Chiu, S., Liu, C., \& Tu, J. (2016). The Influence of Tourists' Expectations on Purchase Intention : Linking Marketing Strategy for Low-Cost Airlines. Journal of Air Transport Management, 53, 226-234.

condorferries. (2020). How Do Travel Trends do Travel Trends Differ Between Gen Z, Millennials, \& Boomers? Discover Booking Habits, Spend \& More! In Travel Statistics by Age Group 2020.

Connelly, B. L., Certo, S. T., Ireland, R. D., \& Reutzel, C. R. (2011). Signaling theory: A review and assessment. Journal of Management, 37(1), 39-67.

Dolbec, P. Y., \& Chebat, J. C. (2013). The Impact of a Flagship vs. a Brand Store on Brand Attitude, Brand Attachment and Brand Equity. Journal of Retailing, 89(4), 460-466.

Dwivedi, A., Nayeem, T., \& Murshed, F. (2018). Brand Experience and Consumers' Willingness-to-pay (WTP) A Price Premium: Mediating Role of Brand Credibility and Perceived Uniqueness. Journal of Retailing and Consumer Services, 44(June), 100-107.

Ekiz, E. H., Hussain, K., \& Bavik, A. (2015). Perceptions of Service Quality in North Cyprus National Airline. Creating Customer Value in Tourism and Hospitality Industry, (April), 778-790.

Erdem, T., \& Louviere, J. (2002). The Impact of Brand Credibility on Consumer Price Sensitivities across Multiple Product Categories. International Journal of Research in Marketing, 19(1), 1-19.

Erdem, T., \& Swait, J. (2004). Brand Credibility, Brand Consideration, and Choice. Journal of Consumer Research, 31(1), 191-198.

Erdem, T., Swait, J., \& Valenzuela, A. (2006). Brands as Signals: A Cross-country Validation Study. Journal of Marketing, $70(1), 34-49$.

Flightconnections. (2020). Garuda Indonesia Routes and Airport Map.

Greenwood, R., Li, S. X., Prakash, R., Deephouse, D. L., Li, S. X., Prakash, R., \& Deephouse, D. L. (2017). Reputation , Diversification, and Organizational Explanations of Performance in Professional Service Firms. 16(6), 661-673.

Iglesias, O., Markovic, S., \& Rialp, J. (2019). How Does Sensory Brand Experience Influence Brand Equity? Considering The Roles of Customer Satisfaction, Customer Affective Commitment, and Employee Empathy. Journal of Business Research, 96(May), 343-354.

Iglesias, O., Singh, J. J., \& Batista-Foguet, J. M. (2011). The role of brand experience and affective commitment in determining brand loyalty. Journal of Brand Management, 18(8), 570-582.

indoindians. (2019, November 27). Best Domestic Airlines in Indonesia. Indoindians.Com.

Jeng, S. P. (2016). The nfluences of Airline Brand Credibility on Consumer Purchase Intentions. Journal of Air Transport Management, 55, 1-8.

Keller, K. L. (2005). Strategic Brand Management Process. Moderne Markenführung, 83-101.

Khan, I., \& Rahman, Z. (2015). Brand experience anatomy in retailing: An interpretive structural modeling approach. Journal of Retailing and Consumer Services, 24(C), 60-69.

Kim, Y. K., \& Lee, H. R. (2011). Customer satisfaction using low cost carriers. Tourism Management, 32(2), $235-243$.

Kirmani, A., \& Rao, A. R. (2000). No pain, no gain: A critical review of the literature on signaling unobservable product quality. Journal of Marketing, 64(2), 66-79.

knoema.com. (2018). Indonesia - Contribution of Travel and Tourism to GDP in Current Prices.

Kos Koklic, M., Kukar-Kinney, M., \& Vegelj, S. (2017). An Investigation of Customer Satisfaction with Low-cost and Fullservice Airline Companies. Journal of Business Research, 80(May), 188-196. 
Lai, W. T., \& Chen, C. F. (2011). Behavioral intentions of public transit passengers-The roles of service quality, perceived value, satisfaction and involvement. Transport Policy, 18(2), 318-325.

Leong, L., Hew, T., Lee, V., \& Ooi, K. (2015). Expert Systems with Applications An SEM - Artificial-Neural-Network Analysis of the Relationships between SERVPERF, Customer Satisfaction and Loyalty among Low-cost and Full-service Airline. Expert Systems with Applications, (May).

Li, Y. Q., \& Liu, C. H. S. (2019). Understanding Service Quality and Reputation Effects on Purchase Behavior through Image: The Moderating Roles of Service Reliability. Transportation Letters, 11(10), 580-588.

Ludwell, K. (2020, January 3). Garuda Indonesia is The Most Punctual Airline in The World. Antaranews.

Martínez Caro, L., \& Martínez García, J. A. (2007). Measuring perceived service quality in urgent transport service. Journal of Retailing and Consumer Services, 14(1), 60-72.

Martínez Caro, L., \& Martínez García, J. A. (2008). Developing a multidimensional and hierarchical service quality model for the travel agency industry. Tourism Management, 29(4), 706-720.

Moreira, A. C., Fortes, N., \& Santiago, R. (2017). Influence of sensory stimuli on brand experience, brand equity and purchase intention. Journal of Business Economics and Management, 18(1), 68-83.

Mukerjee, K. (2018). The impact of brand experience, service quality and perceived value on word of mouth of retail bank customers: Investigating the mediating effect of loyalty. Journal of Financial Services Marketing, 23(1), $12-24$.

Muslim, A., Harun, A., Ismael, D., \& Othman, B. (2020). Social media experience, attitude and behavioral intention towards umrah package among generation X and Y. Management Science Letters, 10(1), 1-12.

Nadiri, H., Hussain, K., Ekiz, E. H., \& Erdogan, S. (2008). An investigation on the Factors Influencing Passengers' Loyalty in the North Cyprus National Airline. The TQM Journal, 20(3), 265-280.

Ngo, L. V., Northey, G., Duffy, S., Thao, H. T. P., \& Tam, L. T. H. (2016). Perceptions of others, mindfulness, and brand experience in retail service setting. Journal of Retailing and Consumer Services, 33, 43-52.

Nikhashemi, S. R., Jebarajakirthy, C., \& Nusair, K. (2019). Uncovering the roles of retail brand experience and brand love in the apparel industry: Non-linear structural equation modelling approach. Journal of Retailing and Consumer Services, 48(October 2018), 122-135.

Nysveen, H., Pedersen, P. E., \& Skard, S. (2013). Brand experiences in service organizations: Exploring the individual effects of brand experience dimensions. Journal of Brand Management, 20(5), 404-423.

Nusairat, N., Hammouri, Q., Al-Ghadir, H., Ahmad, A., \& Eid, M. (2020). The effect of design of restaurant on customer behavioral intentions. Management Science Letters, 10(9), 1929-1938.

Park, H., \& Almanza, B. (2020). What Do Airplane Travelers Think about the Cleanliness of Airplanes and How Do They Try to Prevent Themselves from Getting Sick? Journal of Quality Assurance in Hospitality and Tourism, 00(00), 1-20.

Prentice, C., Wang, X., \& Loureiro, S. M. C. (2019). The influence of brand experience and service quality on customer engagement. Journal of Retailing and Consumer Services, 50(February), 50-59.

Rajaguru, R. (2016). Role of value for money and service quality on behavioural intention: A study of full service and low cost airlines. Journal of Air Transport Management, 53, 114-122.

Refundor. (2020, January 6). Full service and low cost airlines: What are the main differences? Refundor.Com.

Saha, G. C., \& Theingi, T. (2015). Service quality, satisfaction, and behavioural intentions A study of low-cost airline carriers in Thailand. (May 2009).

Sahin, A., Kitapçi, H., Altindag, E., \& Gök, M. S. (2017). Forum: Investigating the impacts of brand experience and service quality. International Journal of Market Research, 59(6), 707-724.

Shafranskaya, I., \& Potapov, D. (2014). An empirical study of consumer-based city brand equity from signalling theory perspective. Place Branding and Public Diplomacy, 10(2), 117-131.

Spry, A., Pappu, R., \& Cornwell, T. B. (2011). Celebrity endorsement, brand credibility and brand equity. European Journal of Marketing, 45(6), 882-909.

Statistica.com. (2019). Number of international tourist arrivals worldwide 1996-2018.

Sweeney, J., \& Swait, J. (2008). The effects of brand credibility on customer loyalty. Journal of Retailing and Consumer Services, 15(3), 179-193.

worldairlineawards. (2020). The World's Best Airlines of 2019.

Wu, H. C., \& Cheng, C. C. (2013). A hierarchical model of service quality in the airline industry. Journal of Hospitality and Tourism Management, 20, 13-22.

Yuniartha, L., \& Winarto, Y. (2019, September 20). Soekarno-Hatta Airport Development: AP II encouraged to finish Terminal 4. PwC Indonesia.

Zarantonello, L., \& Schmitt, B. H. (2013). The impact of event marketing on brand equity: the mediating roles of brand experience and brand attitude. International Journal of Advertising, 32(2), 255-280. 
(C) 2020 by the authors; licensee Growing Science, Canada. This is an open access article distributed under the terms and conditions of the Creative Commons Attribution (CC-BY) license (http://creativecommons.org/licenses/by/4.0/). 